\title{
Role of Substrates Used for Green Roofs in Limiting Rainwater Runoff
}

\author{
Anna Baryła ${ }^{*}$, Agnieszka Karczmarczyk¹, Agnieszka Bus ${ }^{1}$ \\ 1 Warsaw University of Life Sciences - SGGW, Faculty of Civil and Environmental Engineering, Department of \\ Environmental Improvement, Nowoursynowska 166, 02-787 Warszawa, Poland \\ * Correspondent author's e-mail: anna_baryla@sggw.pl
}

\begin{abstract}
The retention of rainwater is one of the main functions of green roofs in urban areas. One of the elements influencing the variability of rainwater retention on green roofs is the configuration of the roof, i.e. the combination of drainage and vegetation layers and plants. In the article, laboratory studies regarding the influence of the vegetation layer of the green roof on the retention of rainwater were carried out, and the influence of changes in the initial moisture content in extensive and intensive substrates on retention were compared. The analysis of seven randomly selected substrates showed that the runoff coefficients range from 0.59 to 0.71 . In the case of the retention, statistically significant differences were observed in terms of the rainfall volume as well as the initial moisture content.
\end{abstract}

Keywords: green roof, substrates, runoff, retention, moisture

\section{INTRODUCTION}

Restoring natural hydrological processes in urbanized areas requires the retention of rainfall in balance with the level prior to urbanization (Burns et al. 2012, Tokarczyk-Dorociak et al. 2017). In areas of forests and meadows, approximately $60-80 \%$ of rainfall is used for evapotranspiration and infiltration (Zhang et al. 2001), whereas in urbanized areas, the surface runoff constitutes such a percentage (Geiger and Dreiseitl 1999). Green roofs are considered one of the effective methods of managing rainwater in urbanized areas (Pęczkowski et al. 2016, Baryła et al. 2017). Such roofs have a high potential of stopping runoff, as they can comprise as much as half of the non-permeable area of cities (Mentens et al. 2006). It is estimated that yearly rainfall retention on green roofs can amount to anywhere from 5 to $85 \%$ (Li and Babcock, 2014, Cipolla et al. 2016, Elliott et al. 2016, Sims et al. 2016). The variability in rainfall retention can be attributed to, among others, the configuration of the green roof (Berndtsson 2010, VanWoert et al. 2005a, Speak et al. 2013). Construction-wise, green roofs are made up of three main elements: the vegetative/surface layer, the substrate, and the retention/ drainage layer (De Nardo et al. 2005, Teemusk and Mander 2007, Getter et al. 2009, Fioretti et al. 2010, Gwóźdz et al. 2016). In green roofs, substrates are usually designed to retain rainwater and support plant growth; hence, the materials characterized by specific physical, chemical and biological properties are used (these are usually mineral-organic or mineral mixtures) (Karczmarczyk et al. 2017). In accordance with DAFA (2015 guidelines), the vegetation layer has to be characterized by a stable structure and store percolating water, making it available to plants and releasing only excess water to the drainage layer. In order to ensure these properties, substrates are made of absorbent materials such as perlite, volcanic lava, pumice, vermiculite and zeolite, from loose salvaged materials, such as red brick and slag, as well as from the materials obtained artificially, such as LECA or pollytag. Moreover, roof substrates (mainly used on intensive roofs) contain organic substances like peat (low moor peat) or compost (Molineux et al. 2009, Kohler and Poll 2010, Aslup et al. 2011, Toland et al. 
2012, Chen 2013). Over the course of their use, the physical properties of substrates undergo changes (Nagase and Dunnett 2011). By mineralization of organic substance, they decrease in volume, and lose their porosity as well as waterholding capacity, which influences the degradation of conditions for plant growth (Bogacz et al. 2013). Research has shown that the structure of a green roof does not appear to be the only factor influencing the rainfall runoff or retention. These factors include the accumulation and intensity of rainfalls (Carter and Ramussen, 2006, Simmons et al. 2008), climatic conditions, seasonality (Mentens et al. 2006), preceding conditions (Bengtsson et al. 2005, Denardo et al. 2005), as well as - though to a lesser degree - the slope of the roof (Villarreal and Bengtsson, 2005, Getter et al. 2007). Despite the studies carried out in many research centres, many questions regarding the influence of different factors on the retention capacity of green roofs still remain.

The aim of the study was: 1 . To confirm that the vegetation layer of a green roof is a significant factor influencing the retention of rainwater; 2 to compare the changes in the moisture content (drying up) in extensive and intensive substrates, as well as its influence on the retention capacity

\section{MATERIALS AND METHODS}

The comparison of retention as well as the influence of the drying out of substrates on the amount of leachate was determined in a laboratory experiment. Seven columns, $144 \mathrm{~mm}$ in diameter, were filled with substrates labelled S 1-7, which had been collected randomly from a local market (Fig. 1). S1 is a substrate of an intensive type, used for the construction of multi-layer roofs. The substrate was taken in the year 2015 from a green roof in the area of Warsaw, built in 2012. The composition of the substrate is: washed sand, mineral grits (chalcedonite, brick, LECA), low moor peat and compost. S2-S4 (intensive type) and S6 (extensive type) are fresh substrates taken from newly-built green roofs or from "large bags", prior to the application. S2 is an intensive substrate that is to be used under lawns or small shrubs; it contains an artificial aggregate (LECA), a mineral aggregate, sand, compost and low-moor peat, as well as a fertilizer. S5 is a growing medium sampled from a fresh prefabricated Sedum mat (Xelo Flor moss-sedum-herbs XF317). Substrates S1-S4 are mixtures of mineral and organic compounds, whereas S6 is a $100 \%$ mineral mixture of crushed red brick, gravel, lime and sand. In the case of substrates S3-S4, no specification could be obtained; the only available information is that they conform to FLL (2008) or DAFA (2015). S7 is a substrate created from crushed red brick. The characteristics of the analysed substrates were compiled in Table 1. All columns were filled with $4 \mathrm{~cm}$ layers, regardless of the substrate type (Fig. 1). The application of different thicknesses for intensive and extensive substrates would have changed the retention abilities, and thus decrease the runoff volume, making it more difficult to compare the results of the experiment.

Prior to the start of the experiment, the columns were irrigated, with the substrates later being watered with the water from the water supply network for 200 days, in doses and according to a schedule developed based on the atmospheric precipitation observed in a nearby weather station (coordinates $52^{\circ} 16^{\prime} 07.16^{\prime \prime} \mathrm{N}, 21^{\circ} 04^{\prime} 89.84^{\prime \prime} \mathrm{E}$ ) in 2013. The volume of runoff was measured by hand after each simulated rainfall. The measurements of the change in moisture and temperature of the substrates were carried out with a WET probe prior to each watering. In the case of mineral substrate S6, it was not possible to carry out the measurements of the moisture contents and temperature, and thus, only the amounts of runoff were measured. The organic matter - OM (\%)

Table 1. Characteristics of substrates used in the study

\begin{tabular}{|c|c|c|c|c|c|c|c|}
\hline Substrate & SI & $\mathrm{S} 2$ & S3 & S4 & S5 & S6 & S7 \\
\hline Type & intensive & intensive & intensive & intensive & extensive & extensive & extensive \\
\hline Age & 3 years & fresh & fresh & fresh & fresh & fresh & fresh \\
\hline Composition & $\begin{array}{c}\text { mineral- } \\
\text { organic }\end{array}$ & $\begin{array}{c}\text { mineral- } \\
\text { organic }\end{array}$ & $\begin{array}{c}\text { mineral- } \\
\text { organic }\end{array}$ & $\begin{array}{c}\text { mineral- } \\
\text { organic }\end{array}$ & no data & mineral & mineral \\
\hline $\mathrm{pH}$ & 7.50 & $7.31^{*}$ & $7.19^{*}$ & $7.60^{*}$ & $8.03^{*}$ & $774^{*}$ & - \\
\hline OM content [\%] & 1.9 & $10.4^{*}$ & $7.0^{*}$ & $7.4^{*}$ & $7.2^{*}$ & $0^{*}$ & 0 \\
\hline Bulk density $\left[\mathrm{kg} / \mathrm{m}^{3}\right]$ & 1083.6 & $1054.8^{\prime *}$ & $105.1^{*}$ & $983.4^{*}$ & $1145.6^{*}$ & $1498.7^{*}$ & 1103.1 \\
\hline
\end{tabular}




\section{RAINFALL}
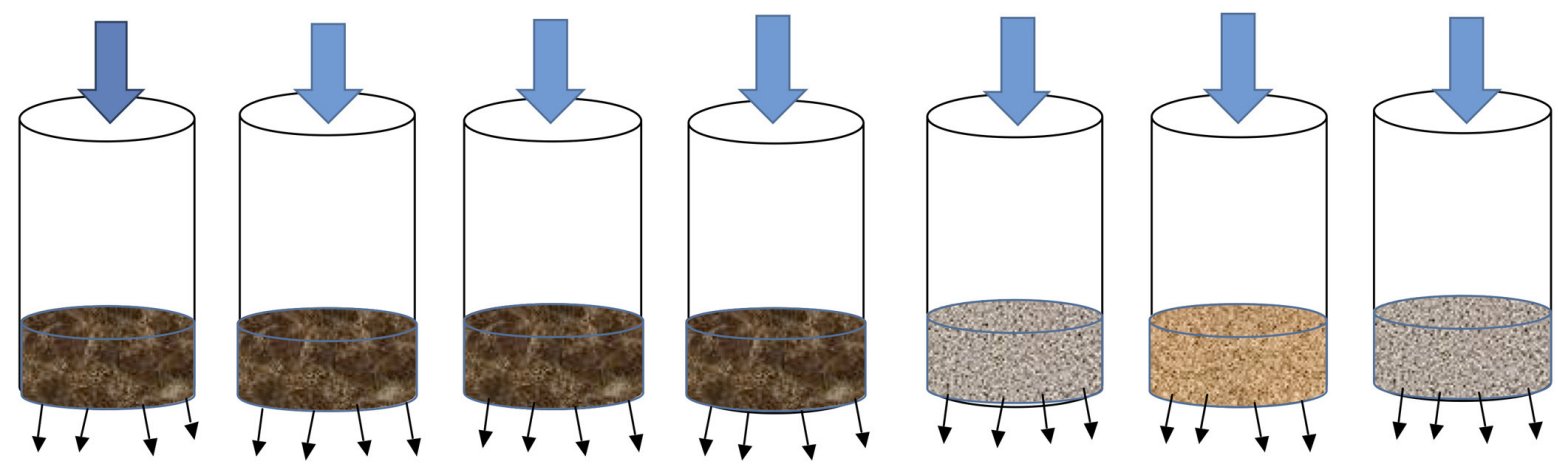

Intensive substrates S1-S4

\section{RUNOFF}

\section{Extensive substrates S5-S7}

Fig. 1 Set up of column experiment

content was defined as the loss of mass following the incineration of samples at a temperature of $550^{\circ} \mathrm{C}$. For $\mathrm{pH}$, the PN-ISO 10390:1997 standard was used, which specifies an instrumental method for the routine determination of $\mathrm{pH}$ using a glass electrode in a 1:5 $(v / v)$ suspension of soil in water. The $\mathrm{pH}$ was measured by means of a Volcraft pH-212 $\mathrm{pH}$ meter.

Rainfall retention in individual trays was calculated in accordance with the formula:

$$
R=\frac{P-Q}{P} \cdot 100 \%
$$

where: $R$ is the runoff retention rate (\%);

$P$ is the rainfall volume $(\mathrm{mm})$;

$Q$ is the runoff depth of green roof (mm).

The article attempts to identify the environmental factors which may play an important role in maintaining the retention of rainwater on a green roof. Two parameters were tested as explanatory variables for the retention of rainwater on green roofs, R (\%), i.e., the rainfall volume and the initial moisture content of the substrate. In order to assess the differences between individual substrates, the analysis of variance (ANOVA) was carried out, allowing for testing the significance of differences between the average values. Next, Tukey's (HSD) multiple comparison test was carried out $(\mathrm{P}<0.05)$. STATGRAPHICS Centurion XIV computer software was used for comparisons and statistical analyses.

\section{STUDY RESULTS}

Over the course of 200 days, each of the columns was watered with a dosage of 774.41 $\mathrm{mm}$ water from the water supply network (Table 2). A total of 80 rainfall events were simulated, the maximum and minimum dosage of which amounted to $48.47 \mathrm{~mm}$ and $3.1 \mathrm{~mm}$, respectively. In the experiment, 48 rainfall events did not exceed $10 \mathrm{~mm}, 24$ fell in the range of $10.1-20.00 \mathrm{~mm}, 4$ in the range of $20.1-30 \mathrm{~mm}$, and 2 events each simulated in the ranges of

Table 2. Experimental data of column leaching experiment

\begin{tabular}{|c|c|c|c|c|c|c|c|}
\hline Substrate & SI & $\mathrm{S} 2$ & S3 & S4 & S5 & S6 & S7 \\
\hline Observation oeriod (days) & \multicolumn{7}{|c|}{200} \\
\hline Precipitation P [mm] & \multicolumn{7}{|c|}{774.41} \\
\hline Volume of leachate $Q[\mathrm{mml}$ & 470.58 & 490.77 & 455.31 & 482.45 & 456.32 & 553.00 & 478.40 \\
\hline $\begin{array}{l}\text { Retention R [\%]: mean } \\
\text { (min-max) }\end{array}$ & $\begin{array}{c}55.13 \\
(8.30-100) \\
\end{array}$ & $\begin{array}{c}52.35 \\
(6.67-100) \\
\end{array}$ & $\begin{array}{c}53.60 \\
(6.30-100) \\
\end{array}$ & $\begin{array}{c}4954 \\
(6.67-100) \\
\end{array}$ & $\begin{array}{c}55.56 \\
(2.12-100) \\
\end{array}$ & $\begin{array}{c}47.02 \\
(1.21-100) \\
\end{array}$ & $\begin{array}{c}51.14 \\
(2.50-100) \\
\end{array}$ \\
\hline $\begin{array}{l}\text { Moisture [\%]: mean (min- } \\
\operatorname{max)}\end{array}$ & $\begin{array}{c}6.83 \\
(2.0-18.4) \\
\end{array}$ & $\begin{array}{c}13.71 \\
(2.7-24.7) \\
\end{array}$ & $\begin{array}{c}12.33 \\
(2.1-22.9) \\
\end{array}$ & $\begin{array}{c}13.27 \\
(2.0-21.6) \\
\end{array}$ & $\begin{array}{c}8.62 \\
(2.2-15.8) \\
\end{array}$ & - & $\begin{array}{c}9.71 \\
(2.2-21.6)\end{array}$ \\
\hline $\begin{array}{l}\text { Substrate temperature } \mathrm{T} \\
{\left[{ }^{\circ} \mathrm{C}\right] \text { : mean (min-max) }}\end{array}$ & $\begin{array}{c}21.81 \\
(19.6-25.7)\end{array}$ & $\begin{array}{c}21.17 \\
(19,6-24,5)\end{array}$ & $\begin{array}{c}20.74 \\
(19.0-24.5)\end{array}$ & $\begin{array}{c}20.57 \\
(18.8-24.2)\end{array}$ & $\begin{array}{c}20.42 \\
(18.7-24,4)\end{array}$ & - & $\begin{array}{c}20.36 \\
(18.5-24.5)\end{array}$ \\
\hline
\end{tabular}


$30.1-40 \mathrm{~mm}$ and $40.1-50.0 \mathrm{~mm}$. The value of average retention in the individual trays was similar: $\mathrm{S} 5(55.6 \%)>\mathrm{S} 1(55.1 \%)>\mathrm{S} 3(53.5 \%)>$ $\mathrm{S} 2(52.4 \%)>\mathrm{S} 7(51.1 \%)>\mathrm{S} 4(49.3 \%)>\mathrm{S} 6(47.0)$. ANOVA showed that there are no statistically significant differences between the groups of retention values obtained for individual columns $-\mathrm{F}_{(6.553)}=0.73 ; \mathrm{p}>0.05$. The Tukey's test which was carried out additionally did not reveal any statistically significant differences between the groups (Fig. 2a).

The initial moisture content varied within the range from $6.83 \%$ to $13.13 \%$ (Table 2). The lowest average moisture value was noted for S1 substrate. This may be connected with the mineralization of organic substances, which often increases along with the age of the substrate (substrate after 3 years of use). ANOVA showed that there are statistically significant differences between the average initial moisture values in the individual columns $-\mathrm{F}_{(5.467)}=28.61$ at $95.0 \%$ level of confidence. In order to determine which groups differed statistically from each other, multiple comparisons using Tukey's test were carried out. On the basis of the test, similarities in S2-S4 columns (fresh intensive substrates) and between S5 and S7 columns (extensive substrates) were confirmed (Fig. 2b). The S1 substrate (intensive substrate after 3 years of use), on the other hand, did not reveal similarities to the remaining columns and was characterized by lower average values (Fig. 2b). Despite the obtained differences in the initial moisture values in the individual trays, such a relationship was not observed in the case of retention.

The temperature of the substrates in the trays ranged, on average, from $20.36^{\circ} \mathrm{C}$ to $21.81^{\circ} \mathrm{C}$, not showing any large changes over the course of the experiment (Tab. 2). The retention ability of S1-S7 substrates decreased along with an increase in rainfalls (Fig. 3), which confirmed the studies of other authors (Carter and Rasmussen 2006; Teemusk and Mander 2007). Teemusk and Mander (2007) showed $85.7 \%$ retention at a rainfall of $2.11 \mathrm{~mm}$. On the other hand, at the rainfalls of over $12 \mathrm{~mm}$, the runoff from green roofs was comparable to that from the reference roof. In Southfield, Michigan (roof thickness of $100 \mathrm{~mm}$ ), Carpenter and Kaluvakolanu (2011) obtained 98.6\% retention for small events (i.e. $<12.6 \mathrm{~mm}$ ), $90.2 \%$ retention for medium events (i.e. $12.7-25.4 \mathrm{~mm}$ ) and $52.7 \%$ in the case of big events (i.e. $>25.4 \mathrm{~mm}$ ).

The obtained negative values of correlations, i.e. S1 (-0.53), S2 (-0.60), S3 (-0.59), S4 (-0.48), S5 (-0.47), S6 (-0.54), S7 (-0.61), for $\mathrm{p}<0.05$, indicated an average relationship between the rainfall volume $(\mathrm{mm})$ and retention ability. The linear model between rainfalls and retention ability explained from 16 to $30 \%$ variance in retention ability in rainfall function (Fig. 3).

The obtained regression coefficients indicate that along with an increase in initial moisture content, the retention ability of substrates decreases.
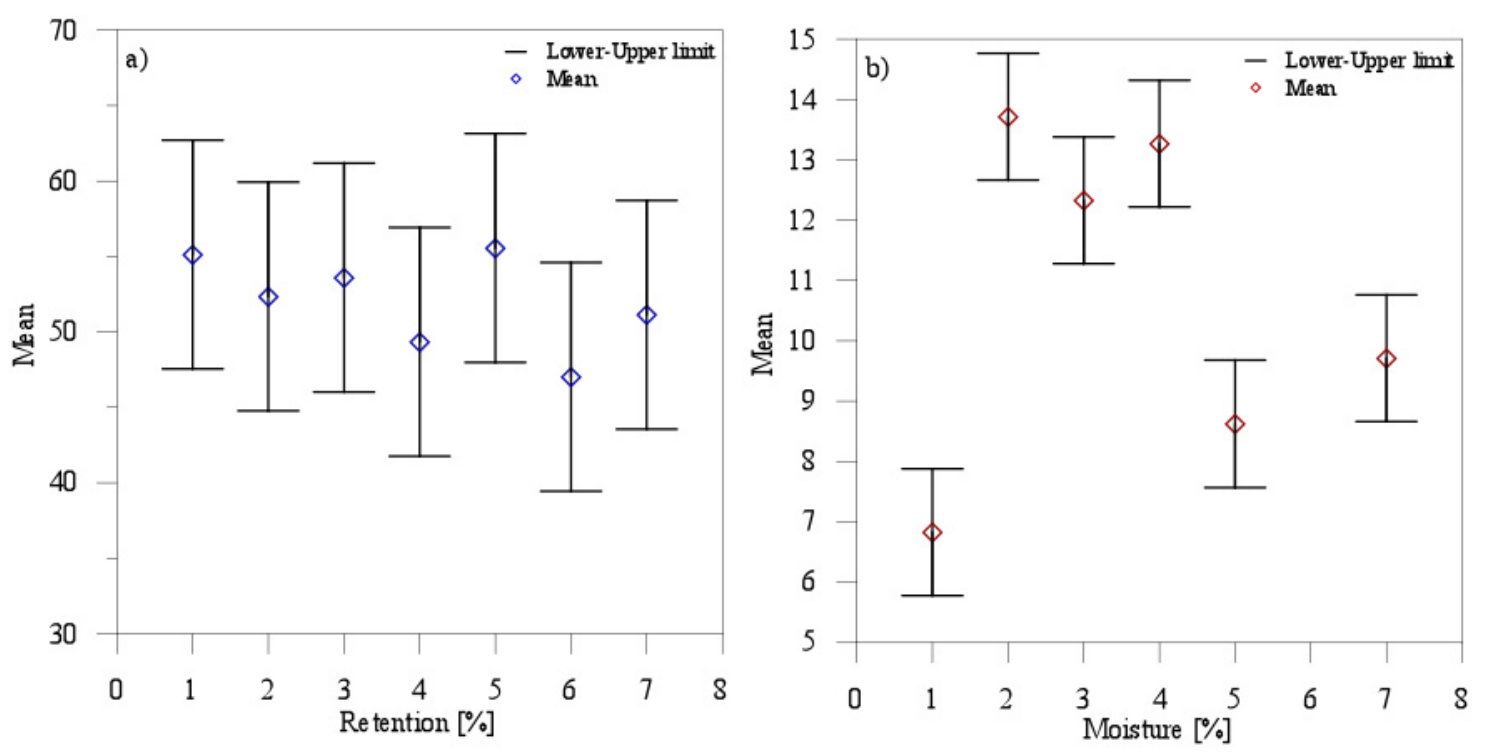

Fig. 2 Result of comparing averages a - left) retention, b - right) initial moisture content in columns with Tukey's interval at $95 \%$ level of confidence 

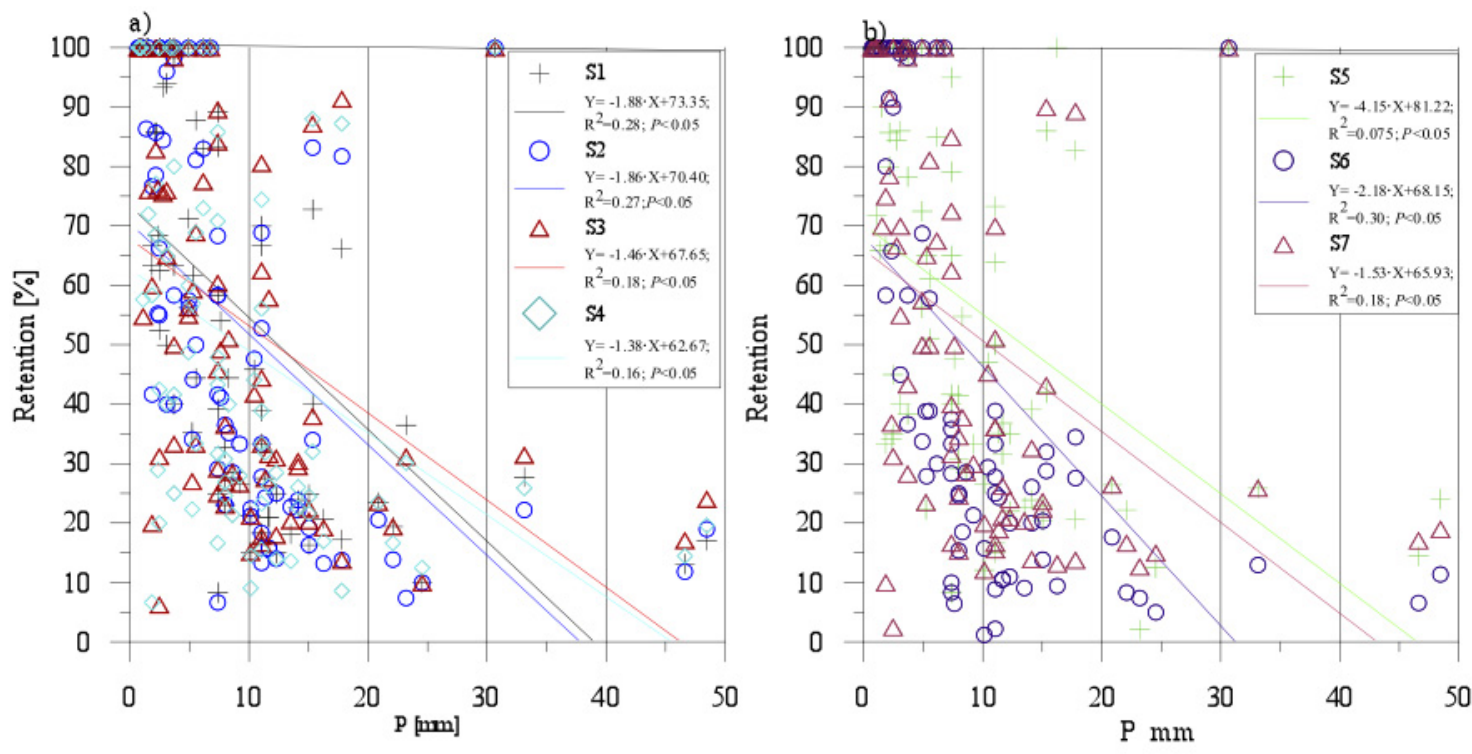

Fig. 3 Relationship between retention R [\%] and rainfall P [mm]

Negative correlation coefficients in the linear relationship between retention and moisture content, were lower than in the relationship between the retention and rainfall volume. The calculated correlation coefficients were: S1(-0.42), S2 $(-0.32)$, S3 (-0.53), S4 (-0.53), S4 (-0.56), S7 $(-0.46)$, which signifies an average relationship. For each pair of variables, statistically significant linear correlations at a significance level of 5\% were determined.

The linear model of relationships between initial moisture content and retention ability explained from 16 to $31 \%$ variance (Fig. 4 ).

\section{CONCLUSION}

The hydrological efficiency of green roofs is influenced by many factors, including the characteristics of rainfalls (rainfall depth, duration and intensity), the roof structure (type and depth of substrate, slope and age of green roof, drainage, and type of vegetation), the length of the dry period, fertilization and maintenance work, local sources of contamination, climate, and seasonal variability (Berndtsson et al. 2006, Morgan et al. 2013, Zhang and Guo 2013, Buffam et al. 2016). Therefore, the results of water retention by green
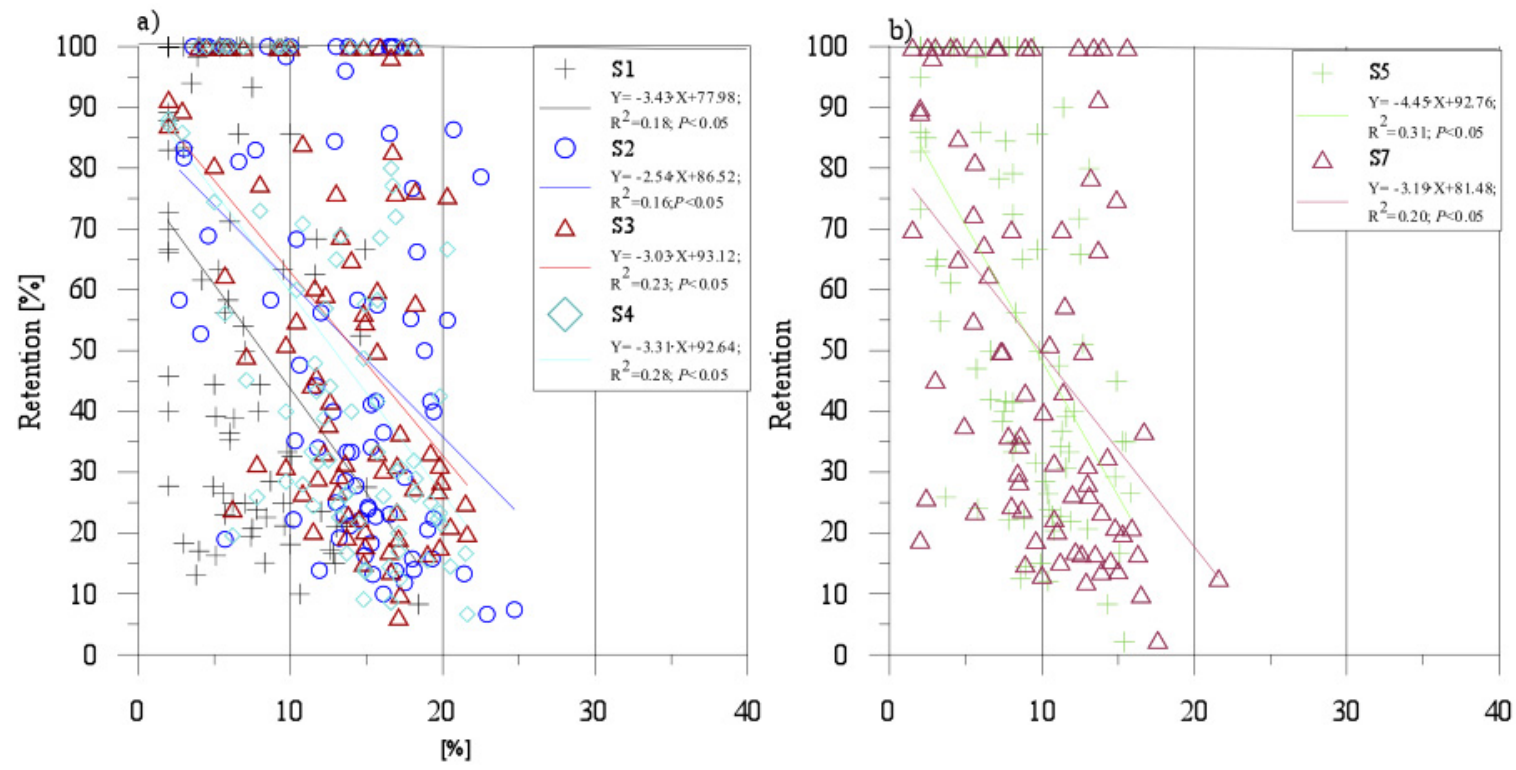

Fig. 4 Relationship between retention $\mathrm{R}[\%]$ and initial moisture content $\theta[\%]$. 
roofs are characterized by large differences. The authors carried out laboratory studies (controlled environment) on the differences and values of the retention abilities of intensive and extensive substrates characterized by different physical properties. The obtained results confirmed that the vegetation layer plays a significant role in the retention of rainwater. The analysis of seven randomly collected substrates showed that the runoff coefficients ranged from 0.59 to 0.71 . Fresh intensive S2-S5 substrates were found to have higher water retention abilities than S6 substrate characterized by a mineral composition. This may stem from the fact that over a longer course of use mineral substrates will be exhibit lower moisture retention abilities, as confirmed by studies carried out by Stovin et al. 2015 and Baryła et al. 2017. In the case of retention, statistically significant differences were observed when it comes to the rainfall volume and initial moisture content. Attention should be drawn to the fact that shallow, extensive systems of green roofs may decrease the risk of flooding, even in the case of torrential rain. Despite all of the analysed substrates showing good retention ability for normal rainfall events, in the case of rainfalls exceeding $20 \mathrm{~mm}$, the maximum observed retention was $39 \%$.

\section{REFERENCES}

1. Aslup S.E., Ebbs S.D., Battaglia L.L., Retzlaff W.A. 2011. Heavy Metals in Leachate from Simulated Green Roof Systems. Ecological Engineering 37, 1709-1717.

2. Baryła, A., Karczmarczyk, A., Bus, A., Kożuchowski, P. 2017. Ocena przydatności wskaźnika opadów uprzednich do opisu uwilgotnienia podłoży na zielonych dachach typu ekstensywnego (Assessing the Usefulness of the Previous Rainfall Indicator in Describing the Moisture Content of Substrates on Extensive Type Green Roofs) [in Polish]. Acta. Sci. Pol., Formatio Circumiectus, 16(4), 23-34.

3. Bengtsson L., Grahn L., Olsson J. 2005. Hydrological Function of a Thin Extensive Green Roof in Southern Sweden. Nordic Hydrol. 36 (3), 259-268.

4. Berndtsson, J. Czemiel 2010. Green Roof Performance Towards Management of Runoff Water Quantity and Quality: a Review. Ecological Engineering 36, 351-360.

5. Bogacz, A., Woźniczka, P., Burszta-Adamiak, E., Kolasińska, K. 2013. Methods of Enhancing Water Retention in Urban Areas. Scientific Review Engi- neering and Environmental Sciences, 22 (1), 27-35 (in Polish).

6. Buffam I., Mitchell M.E., Durtsche R.D. 2016. Environmental Drivers of Seasonal Variation in Green Roof Water Quality. Ecological Engineering 91, 506-514.

7. Burns M.J., Fletcher T.D., Walsh C.J., Ladson A.R., Hatt B.E. 2012. Hydrologic Shortcomings of Conventional Urban Stormwater Mmanagement and Opportunities for Reform. Landsc. Urban Plan. 105, 230-240.

8. Carpenter D., Kaluvakolanu P. 2011. Effect of Roof Surface Type on Stormwater Run-off from Full-scale Roofs in a Temperate Climate. J. Irrigat. Drain. Eng. 137, 161-169.

9. Carter T.L. Rasmussen T.C. 2006. Hydrologic Behavior of Vegetated Roofs. Journal of the American Water Resources Association 42 (5), 1261-1274.

10. Chen C.F. 2013. Performance Evaluation and Development Strategies for Green Roofs in Taiwan: A review. Ecological Engineering, 52, 51-58.

11. Cipolla S.S., Maglionico M., Stojkov I. 2016. A Long-term Hydrological Modelling of an Extensive Green Roof by Means of SWMM. Ecological Engineering 95, 876-887.

12. DeNardo J.C., Jarett A.R., Manbeck H.B., Beattie D.J., Berghage R.D. 2005. Stormwater Mitigation and Surface Temperature Reduction by Green Roofs. Trans. ASAE 48 (4), 1491-1496.

13. DAFA. Dachy zielone. 2015. Wytyczne do Projektowania, Wykonywania i Pielęgnacji Dachów Zielonych-Wytyczne dla Dachów Zielonych (Guidelines for Designing, Constructing and Caring for Green Roofs - Guidelines for Green Roofs) [in Polish]; Stowarzyszenie Wykonawców Dachów Płaskich i Fasad (DAFA): Opole, Poland.

14. Elliott R.M., Gibson R.A., Carson T.B., Marasco D.E., Culligan P.J., McGillis W.R. 2016. Green Roof Seasonal Variation: Comparison of the Hydrologic Behavior of a Thick and a Thin Extensive System in New York City. Environ. Res. Lett. 11, 074020.

15. Fioretti R., Palla A., Lanza L. G., Principi P. 2010. Green Roof Energy and Waterrelated Performance in the Mediterranean Climate. Building and Environment, 45, 1890-1904.

16. FLL 2008. Forschungsgesellschaft Landschaftsentwicklung Landschaftsbau (FLL). Guidelines for the Planning, Construction and Maintenance of Green Roofing - Green Roofing Guideline; FLL: Bonn, Germany.

17. Geiger W. Dreiseitl H. 1999. Nowe sposoby odprowadzania wód deszczowych (New Means of Rainwater Drainage) [in Polish] Poradnik retencjonowania i infiltracji wód deszczowych do gruntu 
na terenach zabudowanych. Oficyna Wydawnicza Projprzem-EKO, Bydgoszcz.

18. Getter K.L., Rowe D.B., Andresen J.A. 2007. Quantifying the Effect of Slope on Extensive Green Roof Stormwater Retention. Ecological Engineering, 31, 225-231.

19. Gwóźdz K., Hewelke E., Źakowicz S., Sas W., Baryła A. 2016. Influence of Cyclic Freezing and Thawing on the Hydraulic Conductivity of Selected Aggregates Used in the Construction of Green Roofs. Journal of Ecological Engineering 17(4), 50-56.

20. International Organization for Standardization (ISO). PN-ISO 10390:1997 Equivalent to ISO 10390:1994 Soil Quality - Determination of $\mathrm{pH}$; ISO: Geneva, Switzerland, 1998.

21. Karczmarczyk A., Baryła A., Kożuchowski P. 2017. Design and Development of Low P-Emission Substrate for the Protection of Urban Water Bodies Collecting Green Roof Runoff. Sustainability 9, 1795.

22. Karczmarczyk A., Bus A., Baryła A. 2018. Phosphate Leaching from Green Roof Substrate - Can Green Roofs Polłute Urban Water Bodies?. Water $10,199$.

23. Köhler M., Poll P.H. 2010. Long-Term Performance of Selected Old Berlin Green Roofs in Comparison to Younger Extensive Green Roofs in Berlin. Ecological Engineering 36, 722-729.

24. Li, Y., Babcock Jr., R.W. 2014. Green Roof Hydrologic Performance and Modeling: a Review. Water Sci. Technol. 69, 727-738.

25. Mentens J., Raes D., Hermy M., 2006. Green Roofs as a Tool for Solving the Rainwater Runoff Problem in the Urbanized 21st Century? Landscape Urban Plann. 77 (3), 217-226.

26. Molineux Ch. J., Fentiman Ch. H., Gange A.C., 2009. Characterising Alternative Recycled Waste Materials for Use as Green Roof Growing Media in the U.K. Ecological Engineering 35, 1507-1513.

27. Morgan S., Celik S., Retzlaff W. 2013. Green Roof Storm-Water Runoff Quantity and Quality. J. Environ. Eng. - ASCE 139 (4), 471-478.

28. Nagase A., Dunnett N. 2011. The Relationship Between Percentage of Organic Matter in Substrate and Plant Growth in Extensive Green Roofs. Landsc. Urban Planning, 103, 230-236.

29. Pęczkowski G., Orzepowski W., Pokładek R., Kowalczyk T. Żmuda R. 2016. Retention Proper- ties of the Type of Extensive Green Roofs as an Example of Model Tests. Acta Sci. Pol., Formatio Circumiectus, 15(3), 113-120 (in Polish).

30. Simmons M.T., Gardiner B., Windhager S., Tinsley J. 2008. Green Roofs are Not Created Equal: the Hydrologic and Thermal Performance of Six Different Extensive Green Roofs and Reflective and Non-reflective Roofs in a Sub-tropical Climate. Urban Ecosyst. 11(4), 339-348.

31. Speak A.F., Rothwell J.J., Lindley S.J., Smith C.L. 2013. Rainwater Runoff Retention on an Aged Intensive Green Roof. Science of the Total Environment, 461-462, 28-38.

32. Sims A.W., Robinson C.E., Smart C.C., Voogt J.A., Hay G.J., Lundholm J.T., et al. 2016. Retention Performance of Green Roofs in Three Different Climate Regions. J. Hydrol. 542, 115-124.

33. Stovin V., Poë S., DeVille S., Berretta C. 2015. The Influence of Substrate and Vegetation Configuration on Green Roof Hydrological Performance. Ecological Engineering 85, 159-172.

34. Teemusk A., Mander Ü. 2007. Rainwater runoff quantity and quality performance from a green roof: The effects of short-term events. Ecological Engineering 30, 271-277.

35. Toland D.C., Haggard B.E., Boyer M.E., 2012. Evaluation of Nutrient Concentrations in Runoff Water from Green Roofs, Conventional Roofs, and Urban Streams. Transactions of the ASABE 55(1), 99-106.

36. Tokarczyk-Dorociak K., Walter E., Kobierska K., Kołodyński R. 2017. Rainwater Management in the Urban Landscape of Wroclaw in Terms of Adaptation to Climate Changes. J. Ecol. Eng. 18(6):171-184.

37. Villarreal, E.L., Bengtsson, L. 2005. Response of a Sedum Green-Roof to Individual Rain Events. Ecological Engineering 25 (1), 1-7.

38. VanWoert N.D., Rowe D.B., Andresen J.A., Rugh C.L., Fernandez R.T., Xiao L. 2005a. Green Roof Stormwater retention. J. Environ. Qual. 34, 1036-1044.

39. Zhang L., Dawes W.R., Walker G.R. 2001. Response of Mean Annual Evapotranspiration to Vegetation Changes at Catchment Scale. Water Resour. Res. 37, 701-708.

40. Zhang S., Guo Y. 2013. Analytical Probabilistic Model for Evaluating the Hydrologic Performance of Green Roofs. J. Hydrol. Eng. 18, 19-28. 